\title{
The Effectiveness of Sechium edule Jacq. Swartz Extract Changes in the Histopathology of Aspirin-Induced Rat Gastritis Model
}

\author{
Hendrika Andriana Silitonga ${ }^{1,2}$, Gontar A. Siregar $^{3 *}$, Rosita Juwita Sembiring ${ }^{4}$, Marline Nainggolan ${ }^{5}$ \\ ${ }^{1}$ Doctoral Program, Faculty of Medicine, Universitas Sumatera Utara, Kota Medan, Indonesia; ${ }^{2}$ Department of Histology, Faculty \\ of Medicine, Universitas Methodist Indonesia, Kota Medan, Indonesia; ${ }^{3}$ Department of Internal Medicine, Faculty of Medicine, \\ Universitas Sumatera Utara, Kota Medan, Indonesia; ${ }^{4}$ Department of Clinical Pathology, Faculty of Medicine, Universitas \\ Sumatera Utara, Kota Medan, Indonesia; ${ }^{5}$ Department of Pharmaceutical Biology, Faculty of Pharmacy, Universitas Sumatera \\ Utara, Kota Medan, Indonesia
}

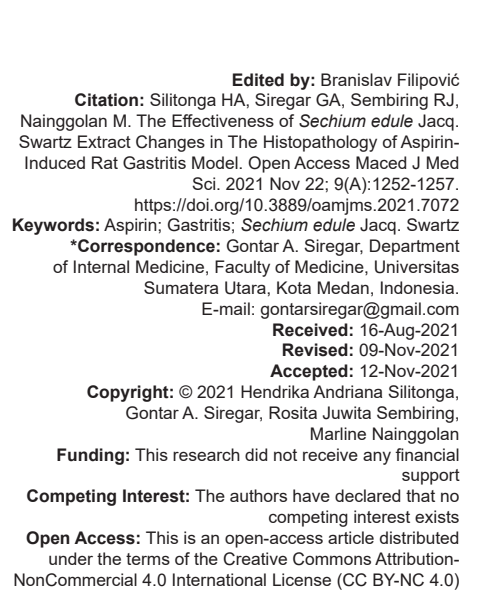

\section{Introduction}

Gastritis is a common health problem, due to the fact that it is frequently diagnosed solely on the basis of clinical symptoms, rather than histological evaluation. Gastritis is an inflammatory condition of the gastric mucosa that can be transient or chronic, widespread, or localized. Gastritis is the gastric mucosa's response to irritants. The gastric epithelium is irritated by a variety of stimuli, both endogenous and exogenous, including $\mathrm{HCl}$, pepsinogen/pepsin, bile salts, and medications, alcohol, and germs [1], [2], [3].

Inflammation is defined by an increase in the number of inflammatory cells in stomach biopsy specimens. There are numerous types of inflammatory cells, including macrophages, neutrophils, lymphocytes, and plasma cells. Gastritis can be classified according to the major inflammatory cell type. If there are numerous neutrophil cells, the condition is acute, but the presence of lymphocytes or plasma cells indicates chronic gastritis. This difference in inflammatory cells is also seen in gastritis caused by Helicobacter pylori, nonsteroidal anti-inflammatory drugs, and chemicals. As a result, inflammatory cells become a critical indicator for diagnosing gastritis [4], [5].

Improving stomach mucosal defenses and reducing inflammation are critical components in treating gastritis. As a result, in the case of gastritis, treatment with medications generated from chemicals may increase inflammatory conditions, necessitating the use of an anti-inflammatory agent derived from nature, namely, chayote (Sechium edule Jacq. Swartz) [6].

Sechium edule (Jacq.) Swartz preliminary phytochemical screening revealed the presence of primary metabolites such as carbohydrates and proteins, as well as secondary metabolites such as saponins, phenols, flavonoids, steroids, tannins, terpenoids, and coumarins [7]. Flavonoids have also been found to have antispasmodic, antisecretory, antidiarrheal, and antiulcer actions in the gastrointestinal system [8], [9]. Due to their antioxidant characteristics, 
flavonoids can help preserve the stomach mucosa, making them useful in the treatment of gastritis. One of the flavonoid compounds is quercetin, which inhibits the histidine decarboxylase enzyme, hence inhibiting histamine generation. Because histamine is a key mediator in inflammatory illnesses, meniran inhibits the inflammatory response caused by histamine in gastritis [10].

Chayote (Sechium edule Jacq. Swartz) may be used to treat gastritis. Sechium edule Jacq. Swartz contains flavonoids that have anti-inflammatory and antioxidant properties, as well as alkaloids that promote in cell regeneration [11], [12]. Thus, it is envisaged that the juice content of chayote (Sechium edule Jacq. Swartz) can be employed to restore the stomach mucosa in rats with aspirin-induced gastritis.

\section{Methods}

\begin{abstract}
Materials
Aspirin (Kimia Farma), ethanol (Bratachem), ethyl acetate (Bratachem), pellet, methanol (Bratachem), hematoxylin (Sigma-Aldrich), eosin (Bratachem), toluene (Bratachem), Aquasterile (Bratachem), and ketamine (Kimia Farma) were used.
\end{abstract}

\section{Animal}

The experimental study used 30 rats (Rattus norvegicus) in good health and weighing between 150 and $200 \mathrm{~g}$. Rats are housed in plastic cages with a humidity level of $40-60 \%$ and a $12 \mathrm{~h}$ dark/light cycle. In addition, rats were given cratachem producing pellet diet and water ad libitum. The University of North Sumatra had granted ethics clearance for this project.

\section{Plant}

Sechium edule Jacq. Swartz was collected in Berastagi, Sumatera Utara, Indonesia, cleaned, dried, and then blended till a dry powder was formed. In addition, the powder obtained was stored at room temperature and opened as needed.

\section{Ethyl acetate extract preparation}

To begin the maceration process, dissolve the Siamese pumpkin (Sechium edule Jacq. Swartz) in a solvent, particularly ethyl acetate in a 1:10 (w/v) ratio, dissolved in 10 parts ethyl acetate, then poured with 75 parts $96 \%$ ethyl acetate. Covered and kept in a dark place for 5 days, stirring occasionally. After 5 days, the solution was filtered, the dregs were squeezed out, and the solution was rinsed with sufficient water to get 100 parts. The juice (Maserati) was transferred to a closed vessel and stored in a cool, shaded area for 2 days. The resulting extract was then evaporated at a temperature of 5000 in an evaporator, dried, and weighed [13].

\section{Ethanol extract preparation}

The maceration procedure begins with dissolving the dregs of Siamese pumpkin (Sechium edule Jacq. Swartz) in ethanol using a solvent, specifically ethanol in a 1:10 (w/v) ratio, dissolved in 10 parts ethanol and then poured with 75 parts $96 \%$ ethanol. Covered and kept in a dark place for 5 days, stirring occasionally. After 5 days, the solution was filtered, the dregs were squeezed out, and the solution was rinsed with sufficient water to get 100 parts. The juice (Maserati) was transferred to a closed vessel and stored in a cool, shaded area for 2 days. The resulting extract was then evaporated at a temperature of $500 \square$ in an evaporator, dried, and weighed [13].

\section{Experimental design}

This study used a sample of 35 male white rats divided into seven groups. Group $\mathrm{K}(-)$ is a negative control group (normal) that received no treatment, Group $\mathrm{K}(+)$ is a positive control group that received aspirin $200 \mathrm{mg} / \mathrm{kg}$ for 3 consecutive days, and Group 1 (P1) is a treatment group that received aspirin $200 \mathrm{mg} / \mathrm{kgBW}$ with chayote ethanol extract $100 \mathrm{mg} / \mathrm{kgBW}$, po, Group 2 (P2) is the treatment group induced by aspirin $200 \mathrm{mg} / \mathrm{kgBW}$ with chayote ethanol extract $200 \mathrm{mg} / \mathrm{kgBW}$, po, Group 3 (P3) is the treatment group induced by aspirin $200 \mathrm{mg} / \mathrm{kgBW}$ with chayote ethyl acetate fraction $100 \mathrm{mg} / \mathrm{kgBW}$, po, and Group 4 (P4) for 28 days, chayote extract and omeprazole were administered. The rats were slaughtered on day 32 using stomach tissue obtained from the antrum-pylorus.

\section{Histopathology preparation}

Antrum-pylorus was taken and the samples were soaked with liquid paraffin at $60-70^{\circ} \mathrm{C}$ for $2 \mathrm{~h}$. It was molded and allowed to freeze, then the paraffin blocks were cut using a microtome with a thickness of $5-7 \mu \mathrm{m}$ and were attached to slides. The organ incision that has been attached to the slide was immediately placed on a heating surface at a temperature of $56-58^{\circ} \mathrm{C}$ for approximately $10 \mathrm{~s}$ so that the organ stretches and sticks to the slide; adjustments were made to avoid wrinkled or folded organs. Further, hematoxylin-eosin staining was carried out. First, the preparations were soaked in xylene solution for the deparaffinization process for $12 \mathrm{~min}$. Next, the dehydration process was carried out by soaking the 
preparations in $70 \%, 80 \%$, and $90 \%$, and absolute ethanol for $5 \mathrm{~min}$, and followed by washing using running water. Subsequently, the preparations were soaked with hematoxylin solution for $5 \mathrm{~min}$, washed with running water, stained with eosin, and then dipped in ethanol $70 \%, 80 \%$, and $90 \%$, and absolute ethanol for $10 \mathrm{~min}$. Finally, the preparations were put in xylene for 12 min. A microscope (Thermo, German) at $\times 100$ was used to observe the preparations.

\section{Results}

\section{Analysis of inflammatory infiltration in gastric histopathology}

The results of the analysis of inflammatory infiltration in gastric histopathology are shown in Table 1.

Table 1: Data inflammatory infiltration in gastric histopathology

\begin{tabular}{llll}
\hline Group & \multicolumn{3}{l}{ Inflammatory infiltration } \\
\cline { 2 - 4 } & None (\%) & Mild (\%) & Strong (\%) \\
\hline K(-) & $4(80)$ & $1(20)$ & - \\
K(+) & - & $2(40)$ & $3(60)$ \\
P1 & - & $5(100)$ & - \\
P2 & - & $5(100)$ & - \\
P3 & - & $5(100)$ & - \\
P4 & - & $5(100)$ & - \\
P5 & - & - & $5(100)$ \\
\hline
\end{tabular}

Table 1 shows inflammatory infiltration in the tip of the group where in Group $\mathrm{K}(+)$ showed moderate inflammatory infiltration as many as 3 mice $(60 \%)$ and 2 mice (40\%) showed mild infiltration in gastric histopathology. Groups P1, P2, P3, and P4 showed mild infiltration (100\%) while in Group P5 as many as 5 mice $(100 \%)$ showed moderate infiltration.

\section{Analysis of acinar glands in gastric histopathology}

The results of the analysis of acinar glands in gastric histopathology in white male rats are shown in Table 2.

Table 2: Data acinar glands in gastric histopathology

\begin{tabular}{llllllll}
\hline Groups & \multicolumn{2}{l}{ Acinar glands } \\
\cline { 2 - 7 } & $\begin{array}{l}\text { Not good } \\
(\%)\end{array}$ & $\begin{array}{l}\text { Partially } \\
\text { improved } \\
(\%)\end{array}$ & $\begin{array}{l}\text { Well } \\
(\%)\end{array}$ & $\begin{array}{l}\text { Atrophy } \\
<25 \% \\
\mathrm{n}(\%)\end{array}$ & $\begin{array}{l}\text { Atrophy } \\
25-50 \%\end{array}$ & $\begin{array}{l}\text { Atrophy } \\
50 \%\end{array}$ & $\begin{array}{l}\text { Atrophy } \\
>75 \%\end{array}$ \\
\hline $\mathrm{K}(-)$ & - & - & $5(100)$ & - & - & - & - \\
$\mathrm{K}(+)$ & - & - & - & - & $1(20)$ & $2(40)$ & $2(40)$ \\
P1 & $1(20)$ & $1(20)$ & $3(60)$ & - & - & - & - \\
P2 & - & $2(40)$ & $3(60)$ & - & - & - & - \\
P3 & $1(20)$ & - & - & - & $1(20)$ & $3(60)$ & - \\
P4 & - & - & - & $1(20)$ & $4(80)$ & - & - \\
P5 & - & - & - & - & $4(80)$ & $1(20)$ & - \\
\hline
\end{tabular}

Table 2 shows the description of the acinar glands on the gastric histopathological picture between the treatment groups.

\section{Discussion}

Gastritis is a common ailment seen in internal medicine clinics and in everyday life. Gastritis is an inflammatory disorder affecting the mucosa and submucosa of the stomach, as well as health problems caused by irritation and infection. Histopathological evidence for this is the presence of inflammatory cells in the area [14].

Gastric biopsy can be used to confirm the diagnosis of gastritis. The purpose of this procedure is to assess the status of the gastric mucosa and to collect information about the diagnosis or prognosis that can be utilized to manage the patient's therapy later on. Erythema, exudative, flat erosion, elevated erosion, hemorrhages, and edematous rugae are all endoscopic characteristics of gastritis. Along with morphological changes, histopathological changes frequently describe the processes underlying the stomach mucosa's adaptive response [15], [16].

Aspirin is an acetylsalicylic acid that may irritate the stomach mucosa and alter the gastric epithelial barrier's permeability [17]. Gastritis and gastropathy are two types of gastric illnesses that can occur as a result of aspirin use [10], [18]. Gastritis caused by aspirin produces irritation of the gastric mucosa due to incomplete dissolution of aspirin pills, stomach absorption, or the presence of prostaglandin inhibition [19].

According to Nanlohy, where aspirin gives a picture of acute inflammation (acute gastritis) in the form of inflammatory cells in the mucous to serous layer, mucosal edema, and capillary dilation. Inflammation is a side effect of aspirin use, namely, irritation of the stomach caused by impaired prostaglandin synthesis. Disruption of prostaglandin synthesis causes impaired blood flow to the mucosal area and loss of the mucus layer that protects the gastric mucosa [20].

Preliminary phytochemical screening of Sechium edule (Jacq.) Swartz consists of primary metabolites, carbohydrates, and proteins and secondary metabolites, saponins, phenols, flavonoids, steroids, tannins, terpenoids, and coumarins [12].

Results of the analysis: The results of the inflammatory infiltration in gastric histopathology in Groups P1, P2, P3, and P4 showed mild inflammatory infiltration compared to Groups $\mathrm{P}(5)$ and $\mathrm{K}(+)$ (Table 2$)$. The mechanism of action of flavonoids as natural antioxidants is to reduce or neutralize free radicals such as ROS and RNS through inhibition of enzymes that produce superoxide anion radicals such as xanthine oxidase and protein kinase. Flavonoids also inhibit cyclo-oxygenase, lipoxygenase, microsomal monooxygenase, glutathione S-transferase, mitochondrial succinate oxidase, and NADH oxidase which are all involved in the formation of ROS so that they can repair damaged tissue [8], [21]. 
Alkaloids reduce gastric acid secretion, increase mucus and alkali secretion, and improve gastric mucosal blood flow so as to help heal and prevent gastric ulcers against irritant agents/factors [9]. Alkaloid compounds reduce gastric acid secretion, increase mucus and alkali secretion, and improve gastric mucosal blood flow so as to help heal and prevent gastric ulcers against irritant agents/factors [22].

The mechanism of the action of saponins as gastroprotective is that saponins work by activating protective factors from the gastric mucous membrane [23]. Saponins have an inhibitory effect

Histopathology of gastric (Figure 1) on gastric mucosal lesions as a protective mucous membrane.

The results of the analysis of acinar gland images on gastric histopathology showed that the P2 group gave a better picture of acinar gland repair than the $\mathrm{K}(+), \mathrm{P} 2, \mathrm{P} 3, \mathrm{P} 4$, and P5 groups (Table 2). The content of flavonoids in chayote is a compound that has pharmacological activity as an anti-inflammatory. The mechanism of flavonoids as anti-inflammatory can be through several pathways, namely, by inhibiting the activity of cyclooxygenase (COX) and lipoxygenase enzymes, inhibiting leukocyte accumulation, inhibiting neutrophil degranulation, and inhibiting histamine release. Inhibition of leukocyte accumulation during the

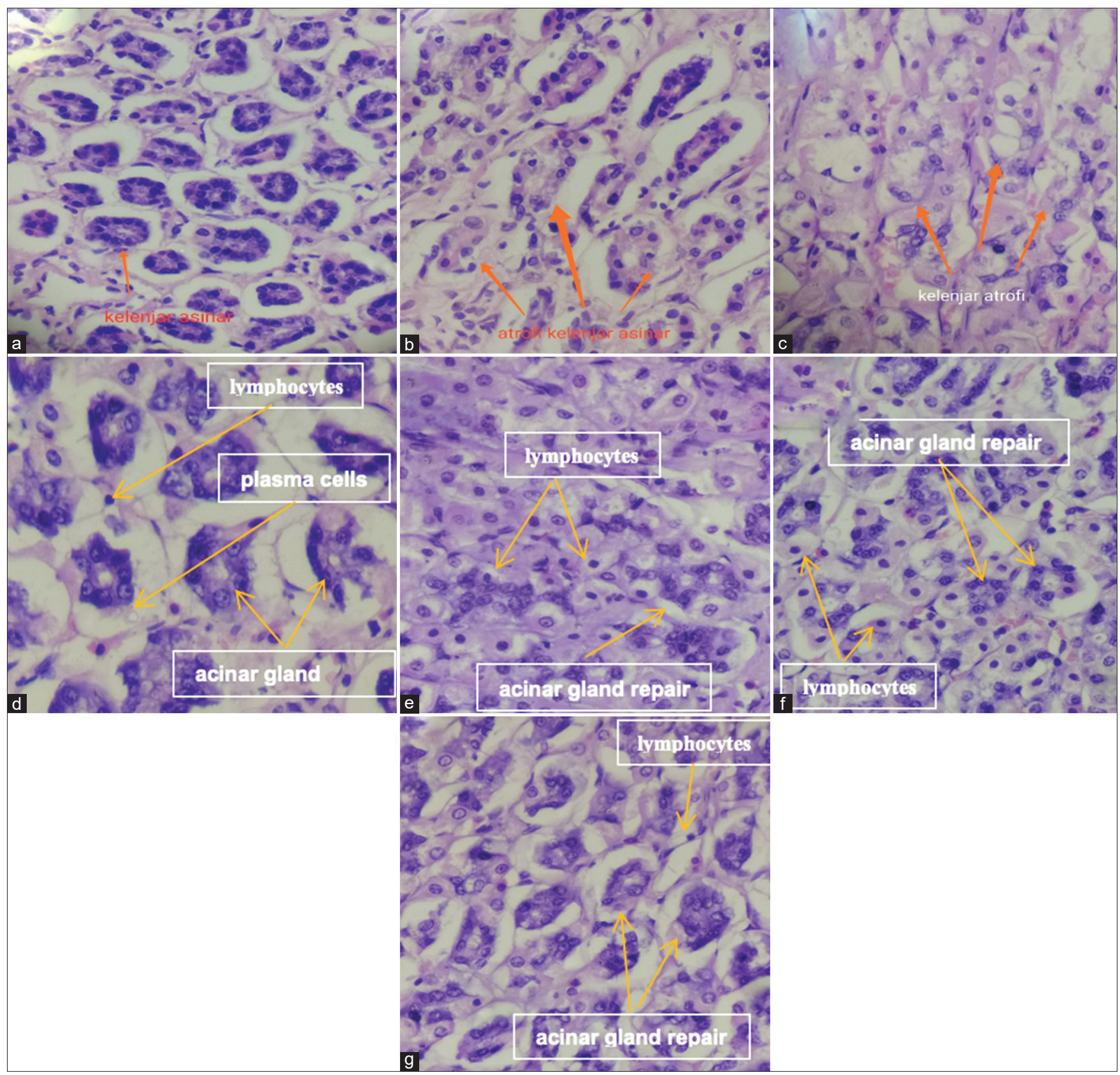

Figure 1: (a) Negative control: Gland appears good, inflammatory cells lymphocytes (-) neutrophils (-); (b) positive control: The acinar glands are mostly atrophic; (c) P1: Minimal aneurysm repair; (d) P2: Gland repair (+) with mild inflammation. Inflammatory cells of lymphocytes and plasma cells; (e) P3: Minimal acinar gland repair, atrophy, with mild lymphocytic cell invasion; (f) P4: Acinar gland repair (+), atrophy, with mild lymphocyte inflammatory cell invasion; (g) P5: Acinar gland repair (+), atrophy, with mild lymphocyte inflammatory cell infiltration (H\&E ×400) 
inflammatory process will cause a decrease in the body's response to inflammation, this inhibition of leukocyte accumulation is due to the inhibition of COX so that thromboxane will be inhibited where this thromboxane will cause leukocyte modulation. Inhibition of neutrophil degranulation will reduce the release of arachidonic acid by neutrophils. Inhibition of histamine release occurs because flavonoids can inhibit the release of histamine from mast cells [24].

In addition, the phenolic content in the chayote fruit is a compound that has potential as an antioxidant by counteracting free radicals in biological systems [5]. Mangiferin, which is a phenolic compound, has been reported to have gastroprotective activity with anti-secretion and antioxidant mechanisms [18].

Tannins are used as traditional medicine due to their astringent effect. This effect can cause tannins to react with tissue proteins. In peptic ulcer disease, it is this layer of tannin-protein complex that protects the stomach by increasing greater defense against irritating factors, tannins can function as antioxidants and increase tissue repair activity due to their anti-inflammatory activity [25].

Microscopic appearance of inflammatory infiltration and acinar glands on gastric mucosa with $\times 400$ with $(A)$ negative control; $(B)$ positive control; (C) ethanol extract $100 \mathrm{mg} / \mathrm{kgBW}$; (D) ethanol extract $200 \mathrm{mg} / \mathrm{kgBW}$; (E) ethyl acetate fraction $100 \mathrm{mg} /$ $\mathrm{kgBW}$; (F) ethyl acetate fraction $200 \mathrm{mg} / \mathrm{kgBW}$; and (G) omeprazole $20 \mathrm{mg} / \mathrm{kgBW}$ showed that the P2 group had a gastroprotective effect for further and chronic gastritis (Figure 1).

\section{Conclusion}

This study shows that ethanol extract of 200 $\mathrm{mg} / \mathrm{kg}$ weight of Sechium edule Jacq. Swartz can reduce inflammatory infiltration and repair of acinar glands in gastric mucosa of aspirin-induced rats compared to $100 \mathrm{mg} / \mathrm{kg}$ weight, ethyl acetate fraction of $100 \mathrm{mg} / \mathrm{kg}$ weight and $200 \mathrm{mg} / \mathrm{kg}$ weight of Sechium edule (Jacq.) Swartz Extract, and omeprazole $20 \mathrm{mg}$.

\section{Acknowledgments}

The authors express their profound gratitude and appreciations to the Universitas Sumatera Utara and Universitas Methodist Indonesia for supporting this research.

\section{References}

1. Xuan J, Deguchi R, Yanagi H, Ozawa H, Urano T, Ogawa $Y$, et al. Relationship between gastric mucosal IL-8 levels and histological gastritis in patients with Helicobacter pylori infection. Tokai J Exp Clin Med. 2005;30(2):83-8. https://doi.org/10.1007/ s00535-005-1630-z

PMid: 16146197

2. Zhaoshen L, Duowu Z, Xiuqiang M, Jie C, Xingang S, Yanfang G, et al. Epidemiology of peptic ulcer disease: Endoscopic results of the systematic investigation of gastrointestinal disease in China. Am J Gastroenterol. 2010;105(12):2570-7.

PMid:20736940

3. Matsui H, Shimokawa O, Kaneko T, Nagano Y, Rai K, Hyodo I. The pathophysiology of non-steroidal anti-inflammatory drug (NSAID)-induced mucosal injuries in stomach and small intestine. J Clin Biochem Nutr. 2011;48(2):107-11. https://doi. org/10.3164/jcbn.10-79

PMid:21373261

4. Campbell KJ, Perkins ND. Regulation of NF-kappa $\beta$ function. Biochem Soc Symp. 2006;73(1):165-80.

PMid:16626297

5. Crabtree JE, Covacci A, Farmery SM. Helicobacter pylor induced interleukin-8 expression in gastric epithelial cells is associated with CagA positive phenotype. J Clin Pathol. 1995;48(1):41-5. https://doi.org/10.1136/jcp.48.1.41 PMid:7706517

6. Tanigawa $\mathrm{T}$, Watanabe $\mathrm{T}$, Higuchi $\mathrm{K}$, Machida $\mathrm{H}$, Yagami $\mathrm{H}$, Watanabe $\mathrm{K}$, et al. Lansoprazole, a proton pump inhibitor suppresses production of tumor necrosis factoralpha and interleukin i beta induced by lipopolysaccharide and helicocobacter pylori bacterial components in human monocytic cells via inhibition of activation of nuclear factor-kappaB and extracellular signal-regulated kinase. J Clin Biochem Nutr. 2009;45(1):86-92. https://doi.org/10.3164/jcbn.08-267 PMid:19590712

7. Zhao X, Wang Q, Qian Y, Song JL. Ilex kudingcha C.J. Tseng (Kudingcha) prevents $\mathrm{HCl} /$ ethanolinduced gastric injury in SpragueDawley rats. Mol Med Rep. 2013;7(10):1613-6. https:// doi.org/10.3892/mmr.2013.1402 PMid:23546392

8. Gupta M, Neera S. Regeneration of beta cells in islet of langerhans of pancreas of alloxan diabetic rats by acetone extract of Momordica charantia (Linn) (bitter gourd) fruits. Indian J Exp Biol. 2006;45(1):1055-62.

PMid:18254212

9. Fenoglio-Preiser CM, Noffdinger AE, Stemmermann GN Lantz PE, Isaacson PG. Gastrointestinal Pathology An Atlas and Text. $3^{\text {rd }}$ ed. Philadelphia, PA: Lippincott Williams \& Wilkins Wolter Kluwer; 2008. p. 155-61.

10. Premkumar G. Preliminary phytochemical and nutritional profiles of an underutilized vegetable Sechium edule (Jacq.) Swartz. South Indian J Biol Sci. 2016;2(1):207-12. https://doi. org/10.22205/sijbs/2016/v2/i1/100399

11. Eamlamnam K, Patumraj S, Visedopas N, Thong-Ngam D. Effects of Aloe vera and sucralfate on gastric microcirculatory changes, cytokine levels and gastric ulcer healing in rats. World J Gastroenterol. 2006;12(13):2034-9. https://doi.org/10.3748/ wjg.v12.i13.2034

PMid:16610053

12. Oluwole FS, Maduabuchi NO, Odetola AA. Antiulcerogenic effects of phyllanthus amarus in rats. Niger J Physiol Sci. 2002;17(2):52-6. 
13. Nijveldt RJ, Nood EV, Hoorn DE, Boelens PG, Norren KV, Leeuwen PA. Flavonoids: A review of probable mechanisms of action and potential applications. Am J Clin Nutr. 2001;74(4):418-25

\section{PMid:11566638}

14. Ebadi MS. Pharmacodinamic Basis of Herbal Medicine. $2^{\text {nd }}$ ed. United States: Taylor and Francis Group; 2007

15. Falcao HD, de Jesus NZ, Gomes IF. Tannins, peptic ulcers and related mechanisms. Int J Mol Sci. 2012;13(3):3203-28. PMid:22489149

16. Nisa S. Gastritis (Warm-e-meda): A review with unani approach. Int J Adv Sci Res. 2018;3(3):43-5.

17. Wahyuni SD, Rumpiati R, Lestarningsih RE. Hubungan pola makan dengan kejadian gastritis pada remaja. Glob Health Sci. 2017;2(2):149-54.

18. Sepulveda RA, Patil M. Practical approach to the pathologic diagnosis ofgastritis.ArchPatholLabMed.2008;132(10):1586-93. https://doi.org/10.5858/2008-132-1586-pattpd

PMid:18834216

19. La Casa C, Villegas I, De La Lastra CA, Motilva V, Martin Calero MJ. Evidence for protective and antioxidant properties of rutin, a natural flavone, against ethanol induced gastric lesions. J. Ethnopharmacol. 2000;71(1):45-53. https://doi.org/10.1016/s0378-8741(99)00174-9

PMid: 10904145

20. Lima JT, Almeida JR, Barbosa-Filho JM, Assis TS, Silva MS, Dacunha EV, et al. Spasmolytic action of diplotropin, a furanoflavan from Diplotropis ferruginea Benth., involves calcium blockade in ginea-pig ileum. Z Naturforsch B. 2005;60:1-8.

21. Dyatmiko W, Maat $S$, Kusumawati I, Eko AT. Sechium edule (Jacq.) Swartz juice on total cholesterol and triglyceride levels in quekerbus mice. J Penel Hayati. 2004;9:139-42.

22. Mills SA, Contos MJ, Goel R. The stomach. In: Silverberg SG, editor. Silverberg's Principles and Practice of Surgical Pathology and Cytopathology. $4^{\text {th }}$ ed., Vol. 2. New York: Churchill Livingstone, Elsevier; 2006. p. 1321-38.

23. Genta RM. Inflammatory disorders of the stomach. In: Odze RD, Goldblum JR, Crawford JW, editors. Surgical Pathology of the GI Tract, Liver, Biliary Tract, Pancreas. Philadelphia, PA: Saunders, Elsevier; 2004. p. 143-76.

24. HirLan. In: Sudoyo AW, editor. Gastritis Dalam Ilmu Penyakit $5^{\text {th }}$ ed., Vol. 1. Jakarta: Interna Publishing; 2009.

25. Rugge $M$, Robert MG, OLGA Group. Staging gastritis: An international proposal. Gastroenterology. 2005;129(5):1807-8. https://doi.org/10.1053/j.gastro.2005.09.056

PMid:16285989 